\title{
Multi-annual variability of global solar radiation in the agricultural area of Lower Silesia (SW Poland) and its relationship with the North Atlantic Oscillation
}

\author{
Krystyna Bryś \\ Wrockaw University of Environmental and Life Sciences, The Faculty of Environmental Engineering and Geodesy, \\ Grunwaldzka 55,50-357 Wrockaw,Poland,e-mail:krystyna.brys@upwr.edu.pl
}

Tadeusz Bryś

Polish Geophysical Society, Wrocław Division, Plac Grunwaldzki 24, 50-363 Wroctaw, Poland, e-mail: tbrys@o2.pl

\begin{abstract}
In this paper, the long-term variability of global solar radiation in the agricultural area of Lower Silesia is analyzed based on a 56-year long (1961-2016) measurement series recorded at the Agro- and Hydro-meteorological Wrocław-Swojec Observatory (SW Poland). Yearly and monthly global radiation sums with their extreme and mean values were compared with radiation data from Warsaw (Central Poland) and Potsdam (East Germany). The dynamics of variability between consecutive months, seasons and years was also taken into account. The conducted positive trends show a significant increase in the investigated global radiation sums for Lower Silesia and also for Central Poland and the eastern part of Germany. The trends are strongly related to long-term macro-circulation changes in the North Hemisphere, particularly with the phases and sub-phases of the North Atlantic Oscillation (NAO). The relations between the investigated values of global solar radiation and these macro-circulation patterns are very complicated and they very often have an asynchronous character. The first, juvenile stage of the NAO positive phase (the 1970s and 1980s), when annual sums of global solar radiation in Wrocław-Swojec reached only the average level of about $3700 \mathrm{MJ} \cdot \mathrm{m}^{-2}$ and warm half-year about $2800 \mathrm{MJ} \cdot \mathrm{m}^{-2}$ respectively, was cloudy and rainy. This period was distinctly different than the advanced stage of one (the 1990's and later years) with bigger sunshine duration and smaller annual precipitation, when the adequate radiation sums amount to $3900-4000 \mathrm{MJ} \cdot \mathrm{m}^{-2}$ and $3000-3100 \mathrm{MJ} \cdot \mathrm{m}^{-2}$ respectively.
\end{abstract}

Keywords: global radiation, multi-annual variability, climate change, NAO

Submitted 5 February 2018, revised 28 August 2018, accepted 30 January 2019

\section{Introduction}

The increasingly widespread use of sustainable sources of clean energy, such as solar energy, which is an alternative of fossil fuels, calls for a comprehensive nationwide identification of such resources. Detailed analysis, taking into consideration the varying volume and dynamics of the resources on both a regional and local scale, is needed, particularly in the context of climate change. Such analysis is possible for the agricultural area of the Lower Silesia region due to the availability of multi-annual data obtained from measurements of global radiation. The present paper is a continuation of the previous studies of the authors (e.g. Bryś 2006, 2007, 2013, 2015, 2017; Bryś, Bryś 2002, $2003,2007)$, with an attempt to determine the parameters and dynamics of the solar features of the climate of Lower Silesia based on radiation trends in Poland.

Past studies on the solar radiation variability in Poland have mainly been based on sunshine duration data (Górski, Górska 2000; Koźmiński, Michalska 2005; Kuczmarska,
Kuczmarski 1998; Kuczmarski 1990; Marciniak, Wójcik 1991; Matuszko 2009, 2014; Morawska-Horawska 1985, 2002; Podstawczyńska 2003, 2007; Podogrocki, Słomka 1993). The influence of circulation and climatic conditions on these distributions was presented in detail by Paszyński and Niedźwiedź (1991), Woś (1999, 2010), Kożuchowski et al. (2000).

A similar analysis for the south-western part of Poland, particularly the Wrocław and Sudety Mts., based on atmospheric circulation, was performed by Bryś (2007), Dubicka (1994, 1998), Dubicka and Karal (1994), Dubicka and Limanówka (1994), Dubicka and Migała (1997), Dubicka and Pyka (2001), Dubicka et al. (1995). The relationship between the structure of solar radiation and sunshine duration in Wrocław was presented by Bryś and Bryś (2003, 2007).

The temporal variability and spatial distribution of global solar radiation in Poland based on selected stations of the Polish actinometrical network for different years from the period of 1961-1995 were analyzed in the works 
of Bogdańska and Podogrocki (2000), Podogrocki (1984, 1989, 2001, 2007). The study of the annual distribution of global radiation in Wrocław and its variability in the years 1961-1980 in relation to macro-circulation weather conditions was made by Dubicka (1994). The potential solar radiation resources of the Lower Silesia (SW Poland) as a source of the so-called clean energy was analyzed by Bryś (2006). The climatic and meteorological conditions necessary for the use of solar energy in Poland were presented by Podogrocki $(1989,2007)$.

Over the past few decades, many studies have pointed out the change of global solar trends, together with an alternation of radiation periods. Since the 1980 s, the so-called period of "dimming", characteristic for earlier decades of the twentieth century, has been displaced by a new "brightening" radiation period (Alpert et al. 2005; Norris, Wild 2007; Ohrvil et al. 2009; Sanchez-Lorenzo et al. 2007, 2017; Stanhill 2005, 2007; Stanhill, Cohen 2001, 2005; Stjern et al. 2009; Streets et al. 2006; Wild 2009; Wild et al. 2005, 2007, 2009). The research performed in Estonia (Russak 1987, 1990; Tooming 2002) and Russia (Abakumova et al. 1996; Abakumova, Bondarenko 2008) and prove that the changes are related both with long-term trends of cloudiness (Kleniewska et al. 2016; Matuszko 2009, 2012; Ohrvill et al. 2009; Stjern et al. 2009; Warren et al. 2007; Wibig 2003, 2004; Żmudzka 2007) and changes in air transparency (Ohrvil et al. 2009; Ruckstuhl, Norris 2009; Sun, Groisman 2000; Uscka-Kowalkowska 2008a, b, 2009, 2013). A great number of research papers point to the anthropogenic genesis of these changes (Ahrens 2008; IPCC 2013; Wibig 2009), yet many other accentuate the importance of natural source factors (Bryś 2005; Bryś, Bryś 2003; Jaworowski 2003, 2007; Kondratyev, Galindo 1997; Marsz 2005, 2010; Marsz, Styszyńska 2002, 2006, 2009; Ohrvil et al. 2009; Pisek, Brazdil 2006; Soon et al 1996). In this context, the key aim of this paper is the presentation of the multi-annual variability of global solar radiation in the agricultural area of Lower Silesia on a broad spatial background, in order to provide new arguments to the discussion on the observed long-term radiation changes in Europe and the North Hemisphere.

\section{Materials and methods}

The Agro- and Hydrometeorology Wrocław-Swojec Observatory $\left(51^{\circ} 07^{\prime} \varphi \mathrm{N}, 17^{\circ} 10^{\prime} \lambda \mathrm{E}, 121 \mathrm{~m}\right.$ a.s.l.) is located in the eastern peripheral, agricultural part of Wrocław (formerly: Breslau). The observatory is located on the side of watershed area, under the hydrological influence of floodwaters from the Odra and Widawa rivers. Such a location facilitates the neutralization of the urban heat island (UHI) and accentuates the frequency of winds from the WNW-NW sector (Bryś 2007a, b). Due to its location and the features of the active area, which is characteristic for agricultural land in the Silesian Lowlands, the results of actinometrical measurements conducted in this area are representative for the eastern part of Wrocław-Magdeburg Ustromtal.

Since 1961, measurements of sunshine duration $(S)$ and global radiation $(K \downarrow)$ have been collected at the height of $1.5 \mathrm{~m}$ above ground level, over the lawn of the observatory. Detailed characteristics in terms of the instrumental and methodological approaches used here can be found in previous papers of the authors (Bryś 2006, 2007, 2013, 2015, 2017; Bryś, Bryś 2002, 2003, 2007), which point to circulation conditions and the influence of the cyclical magnetic activity of the sun (Wolf number) on the analyzed actinometrical data.

The research is based on the revised, continuous and homogenous 56-year long measurement series (19612016) of global radiation (Bryś 2017). The paper presents average and extreme (monthly, annual) values and variability of the analyzed radiation fluxon a seasonal and yearly basis, as such dynamic aspects play an important role in climatological analysis. The paper also includes a comparative approach to respective data from Warsaw (1961-2015), as a relatively representative area for the central part of Poland $^{1}$ (Bogdańska, Podogrocki 2000; Podogrocki 2007), and Potsdam (1950-2016), as representative area for the eastern part of Germany ${ }^{2}$.

\section{Measurement results and discussion}

The course of global radiation $K \downarrow$ in the period of 1961-2016 (Fig. 1) is marked by a strong positive trend, with the wave-like variability of the moving sums of 12 - and 60 -month periods. It only partly corresponds to a solar cyclicity of approximately 11-12 years of length, as the influence of the multiannual variability of circulation is prevalent. It is important to contrast the cloudy and rainy period of the 1970s and 1980s, when annual sums of $K \downarrow$ reached only the average level of approximately $3700 \mathrm{MJ} \cdot \mathrm{m}^{-2}$ compared to later years with smaller annual precipitation levels (Bryś, Bryś 2002; Bryś 2017), when the adequate radiation sums amount to $3900-4000 \mathrm{MJ} \cdot \mathrm{m}^{-2}$. It is indicative that annual sums for sunshine duration in the first period reached the average level of $1300 \mathrm{hrs}$, followed 1600-1700 hrs in the next period (Bryś 2015, 2017).

The extreme annual values of $K \downarrow$ were recorded 8 or 12 years later than the respective values obtained for sunshine

\footnotetext{
${ }^{1}$ ttp://wrdc.mgo.rssi.ru

${ }^{2}$ http://www.klima-potsdam.de/
} 


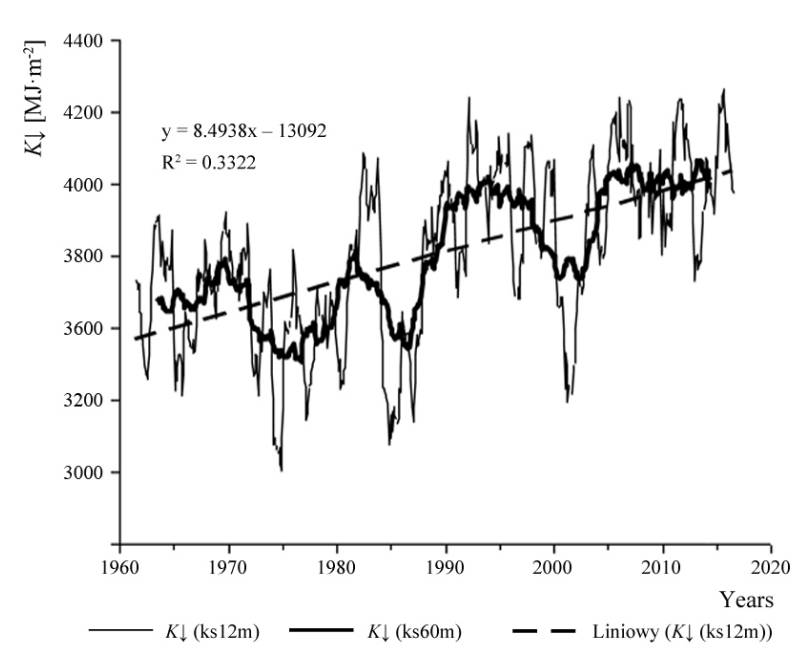

Fig. 1. The runs of 12 - and 60 -month (mean yearly values) moving sums (ks12m and ks60m) of global radiation $K \downarrow$ in WrocławSwojec in the years of 1961-2016 (Liniowy = Linear trend)

duration (Bryś 2015, 2017), which indicates the effect of circulation conditions on these differences, as well as a considerable independence of direct radiation from the global radiation. A minimum $K \downarrow\left(3257.3 \mathrm{MJ} \cdot \mathrm{m}^{-2}\right.$, that is $904.8 \mathrm{kWh} \cdot \mathrm{m}^{-2}$ ) was recorded in 1974 ( 8 years later than the minimum $S$ ). The first maximum $\left(4246.7 \mathrm{MJ} \cdot \mathrm{m}^{-2}\right.$, i.e. $\left.1179.6 \mathrm{kWh} \cdot \mathrm{m}^{-2}\right)$ was observed in 2015 (12 years later than the maximum $S$ ), and the second maximum in magnitude $\left(4227.1 \mathrm{MJ} \cdot \mathrm{m}^{-2}\right.$, i.e. $\left.1174.2 \mathrm{kWh} \cdot \mathrm{m}^{-2}\right)$ in $2011(8$ years later than the maximum $S$ ). The mean annual sum for the period (1971-2000) amounted to $3751.6 \mathrm{MJ} \cdot \mathrm{m}^{-2}$ (i.e. $1042.1 \mathrm{kWh} \cdot \mathrm{m}^{-2}$ ), while for the 50 - and 56 -year long periods, the sums were calculated as $3773.6 \mathrm{MJ} \cdot \mathrm{m}^{-2}$ and $3802.9 \mathrm{MJ} \cdot \mathrm{m}^{-2}$ (i.e. 1048.2 and $1056.4 \mathrm{kWh} \cdot \mathrm{m}^{-2}$ ), respectively.

For the purpose of determining the climate change influence on global radiation and solar energy resources in the Silesian Lowlands, it is important to consider the dynamics of radiation variability. The linear trend of global radiation in Wrocław-Swojec in the years of 1961-2016 (Fig. 1) shows a growth of annual $K \downarrow$ sums by $407,8 \mathrm{MJ} \cdot \mathrm{m}^{-2}$ (i.e. $113.3 \mathrm{kWh} \cdot \mathrm{m}^{-2}$ ) within 50 years and by $457,7 \mathrm{MJ} \cdot \mathrm{m}^{-2}\left(\right.$ i.e. $127.1 \mathrm{kWh} \cdot \mathrm{m}^{-2}$ ) within 56 years.

For all seasons (Fig. 2), a significant positive trend of the 3-month sums of global radiation $K \downarrow$ can be observed. The strongest trend ( $\left.a=3.808, R^{2}=0.347\right)$ is recorded in spring (March-May). A weaker trend is observed in summer ( $\left.a=2.991, R^{2}=0.137\right)$, as the highest values of $K \downarrow$ for this season were already recorded in the first part of the 1990s. The weakest seasonal trend is characteristic for winter $\left(a=0.469, R^{2}=0.077\right)$, so but the changes are jointed with the time when the values of $K \downarrow$ are the lowest in the year.

The very significant positive trend of the $K \downarrow$ sums of the warm half-year (April-September) (Bryś 2017) is also reached (Fig. 3). In these sums, which are of crucial importance to the values for the $K \downarrow$ yearly sums (of which they constitute on average $77.8 \%$ ), as well as in the appropriate annual (Jan.-Dec.) sums, a significant increase (Bryś 2017) in values is recorded (approx. $250 \mathrm{MJ} \cdot \mathrm{m}^{-2}$ for the half-year sums) between the two circulation periods (early and advanced) of the NAO (North Atlantic Circulation) positive phase. For the target time periods of the $K \downarrow$ yearly and half-year sums (distinctly visible in the runs of the 60-month moving sums), a boundary can be seen at year 1987, between the earlier period (1961-1987) with relatively low values of these sums and the later period (1988-2016), with relatively high values of these sums. Such a division of the study period of 1961-2016 is not only induced by an evident radiation turning point, which appears in the research of actinometrical series (Bryś 2013, 2017), but also occurs in similar series of air temperature $T p$, saturation deficit $d$ and precipitation $P$ in Wrocław (Bryś 2017). There are significant macro-circulation reasons behind this, and therefore, such a division appears also in the mean NAO indexes for the warm half-year and summer (Bryś 2017), that is, in the periods when the maximum yearly $K \downarrow, T p$, $d, P$ values in Wrocław are observed.

The first period includes the advanced and last stages of the negative phase of the NAO (1955-1973, or up until 1978), and the juvenile stage of the positive phase of the NAO (1974-1987, or 1979-1987). The 1974-1978 years include a turning point, and therefore it is very difficult to fix a precise time boundary between these phases (Hurrel 2017; Marsz, Styszyńska 2002, 2006). For the years of 1979-1987, an abrupt transition to recurring positive phases of the NAO is observed, occurring during the 1979/80 winter. In addition, a substantial negative phase of the pattern appeared twice, in the winters of $1984 / 85$ and $1985 / 86^{3}$. The second analyzed period (1988-2016) includes the advanced stage of the positive phase of the NAO. However, the period of November 1995 to February 1996 was characterized by a return to the strong negative phase of the NAO, with later years dominated by evident positive values of the wintertime NAO.

The precise distinction of these phases and stages is not an easy task and is still the subject of research and discussion (Bryś, Bryś 2002; Marsz, Styszyńska 2002, 2006; Wibig 2000, 2001) $)^{4}$. Most often, the relationship between changes of the NAO and European climate are considered as teleconnections of different NAO winter patterns with continental temperature and precipitation (Hurrell 1995;

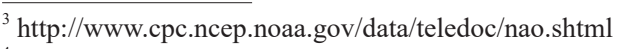

${ }^{4}$ see also: http://www.cpc.ncep.noaa.gov/data/teledoc/nao.shtml 2017; https://climatedataguide.ucar.edu/climate-data/hurrell-north-atlanticoscillation-nao-index-station-based
} 

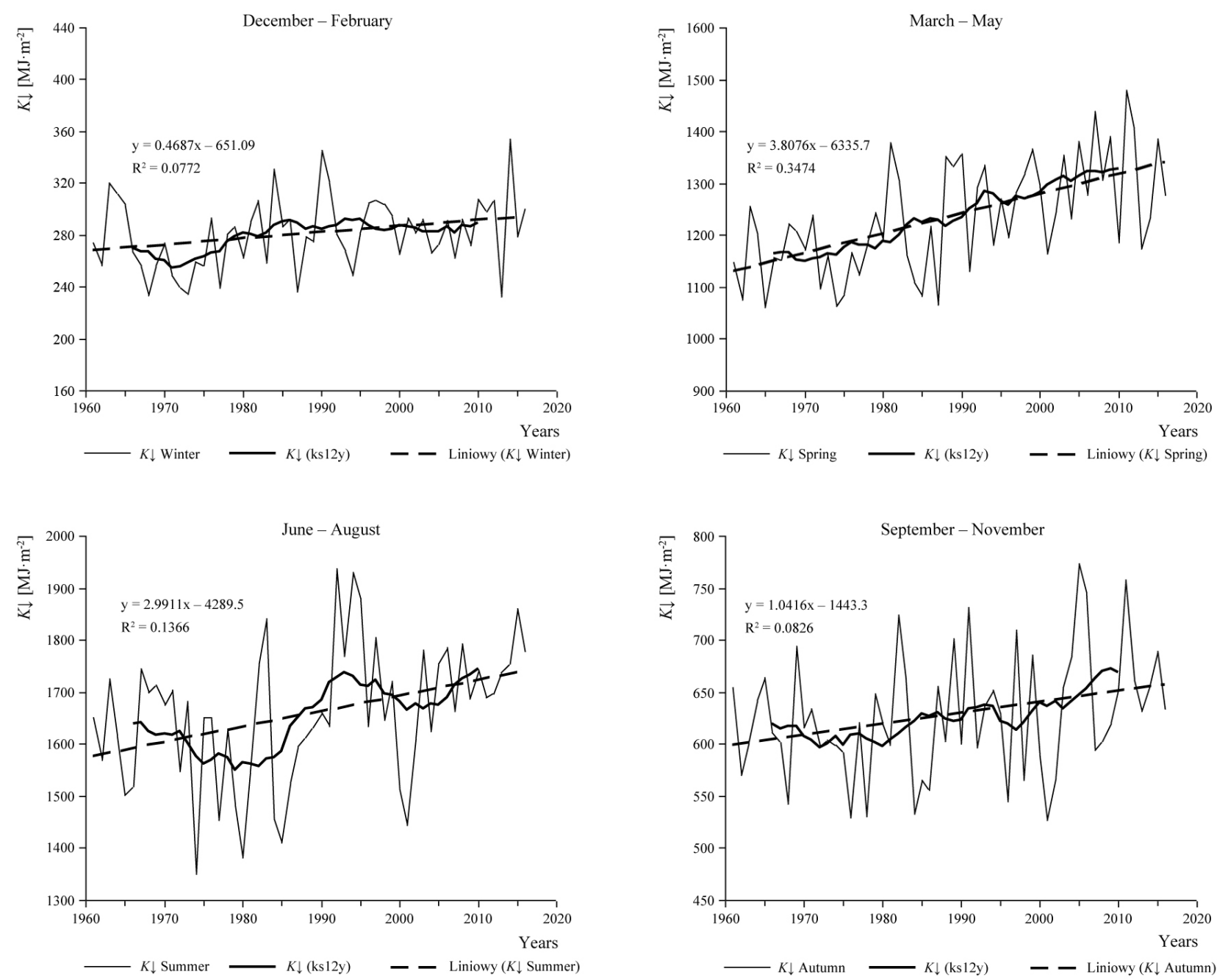

Fig. 2. The courses of seasonal (winter XII-II, spring III-V, summer VI-VIII, autumn IX-XI) sums of global radiation $K \downarrow$ and their 12-year (ks12y) moving averages in Wrocław-Swojec in the years of 1961-2016 (Liniowy = Linear trend)
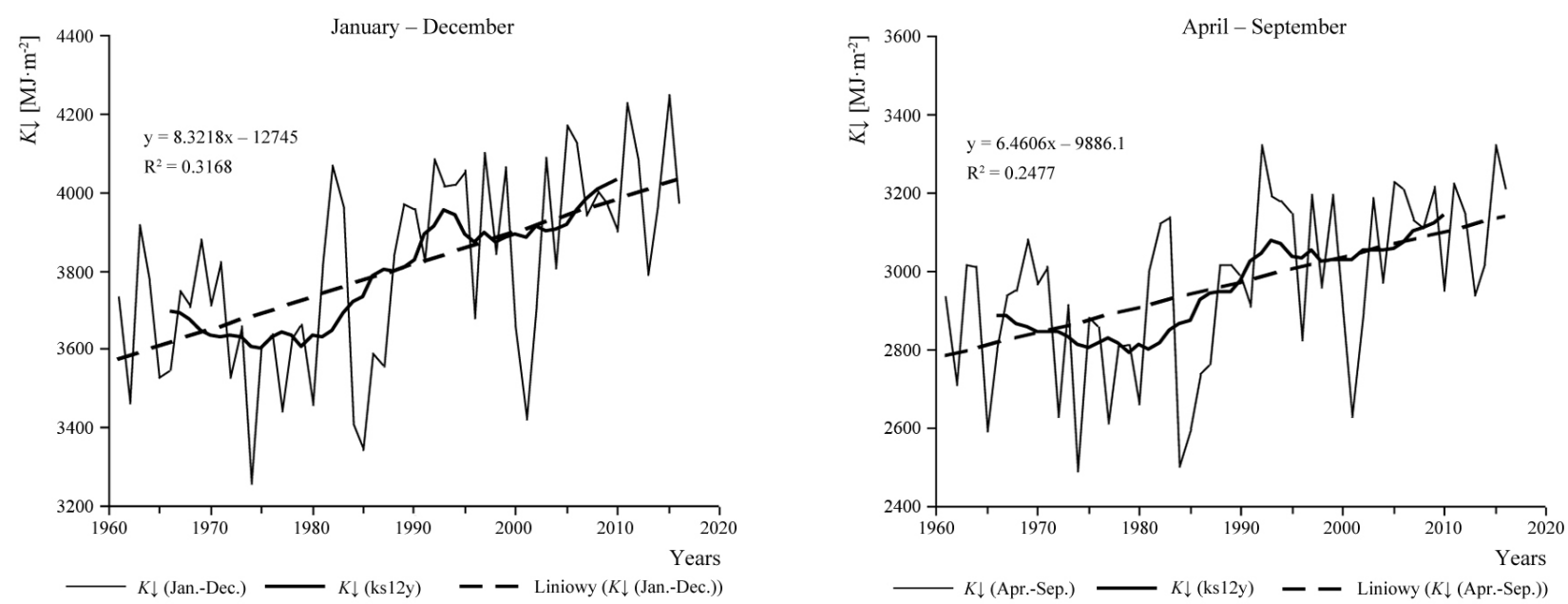

Fig. 3. The runs of annual (Jan.-Dec.) and half-year (Apr.-Sep.) sums of $K \downarrow$ and their 12-year (ks12y) moving averages in WrocławSwojec in the years of 1961-2016 (Liniowy = Linear trend)

Marsz 2005; Marsz, Styszyńska 2002, 2006). The problem of teleconnections between NAO and monthly sums of $K \downarrow$ in Wrocław is only considered in the earlier studies of the authors (Bryś, Bryś 2002; Bryś 2017). There exists a lack of similar studies for other areas in Poland and Central Europe, thus the current study also takes into consideration Potsdam and Warsaw.

The courses of monthly mean values of global radiation intensity $K \downarrow$ in Wrocław-Swojec between the years 1961-2016 (Fig. 4) show that the most important trends 
in the spring and summer growth of $K \downarrow$ are found in April $\left(a=0.549, R^{2}=0.207\right)$, May $\left(a=0.619, R^{2}=0.137\right)$, and August $\left(a=0.467, R^{2}=0.147\right)$. Also significant is the positive trend for March $\left(a=0.272, R^{2}=0.105\right)$, and the increasing trend for July $\left(a=0.446, R^{2}=0.064\right)$ (with a significance of $p=0.062$ for Spearman's test and $p=0.075$ for tau-Kendall's test). For the autumn period, there is a significant, positive trend for November ( $a=0.119, R^{2}=0.123$ ), whereas for winter an increasing trend for February ( $\left.a=0.131, R^{2}=0.055\right)$ is observed, which is not, however, significant ( $p=0.115$ of Spearman's test, $p=0,116$ of tau-Kendall's test).

In many monthly courses, the interesting phenomenon, particularly in February, July, August and October, of a strong wave characterizing the 12-year (ks12y) moving averages is observed (Fig. 4). The top of the wave in February coincides with the second part of the 1980s, while July and October it is observed in first part of the1990s, and in August, in the mid-1990s and the first years of second part of the 1990s. The similar top of the wave for the whole summer season is observed in the first part of the 1990s (Fig. 2), as with the whole year and warm half-year (Fig. 3). Most likely, for these last cases (Fig. 3), a new wave is current forming, or will form in the close future (around 2020). Such phenomena are an important radiation feature of natural climatic fluctuations over many years.

Similar trends and variations of $K \downarrow$ annual sums between the two compared circulation periods were reached in Potsdam (Fig. 5 and Fig. 6) and Warsaw (Fig. 6). As in Wrocław, for these stations, a boundary is noted around year 1987, between the first period (1961-1987) with low values of these sums and the later period (1988-2015, or 2016), with relatively high values of these sums. A comparison of trends for Potsdam, Wrocław and Warsaw proves that the strongest positive trend of $K \downarrow$ annual sums is observed in Warsaw (Fig 6), closely followed by Wrocław (Fig. 3 and Fig. 7), and the weakest in Potsdam (Fig. 5 and Fig. 6).

In the period of 1961-2015, the highest annual sum of $K \downarrow$ was noted in Wrocław (4246.7 MJ.m ${ }^{-2}$ in 2015), 2.1\% lower in Potsdam (4 158.6 MJ.m $\mathrm{m}^{-2}$ in 2003), and 5.0\% lower than the Wrocław maximum in Warsaw $\left(4033.2 \mathrm{MJ} \cdot \mathrm{m}^{-2}\right.$ in 2012). The lowest minimum annual sums of $K \downarrow$ were registered in Potsdam (3 195.2 $\mathrm{MJ} \cdot \mathrm{m}^{-2}$ in 1984), followed by Warsaw (3217.2 $\mathrm{MJ} \cdot \mathrm{m}^{-2}$ in $1980,0.7 \%$ larger than in Potsdam), and in Wrocław (3257.4 MJ.m ${ }^{-2}$ in $1974,1.9 \%$ larger than in Potsdam). The highest annual average sum in the 55-year research period appears in Wrocław (3 $799.9 \mathrm{MJ} \cdot \mathrm{m}^{-2}$ ), which is $2.8 \%$ higher than in Potsdam (3 $694.9 \mathrm{MJ} \cdot \mathrm{m}^{-2}$ ), and $3.5 \%$ higher than that in Warsaw $\left(3671.6 \mathrm{MJ} \cdot \mathrm{m}^{-2}\right)$. The coefficient of variability for the annual sums of $K \downarrow$ averages is $5.6 \%$ for Potsdam, and $6.4 \%$ for both Warsaw and Wrocław. The relatively low annual sums of $K \downarrow$ for Warsaw in comparison to Belsk, Puławy, and other suburban areas in the radius of approximately $100 \mathrm{~km}$ from Warsaw, proves that the radiation values registered in Warsaw were reduced due to the influence of a greater amount of cloudiness generated by a very intensive UHI (Urban Heat Island) and local strong atmospheric pollution (Bogdańska, Podogrocki 2000; Górski, Górska 2000; Podogrocki 1984; Podogrocki, Słomka 1993). However, the radiation data from station Warsaw-Bielany is included in the longest actinometrical series in Poland, thus they have a relatively representative character for the central part of Poland, which is the main aim of the current analysis.

The relationship between $K \downarrow$ and macro-circulation conditions are very complicated and are linked to oceanic influences based on the solar features of the climate in Central Europe, which varies in time. This influence is a natural derivative of source impact of sun activity on the Earth's climate (Soon et al. 1996) and of the important role of the contrast between the land and the ocean, as two different active global surfaces. They form, together with the influence of the Earth's rotary and circumsolar movement and other astronomical and geophysical conditions (particularly volcanic activity), the main features of a heat, moisture and momentum transfer and climatic diversification, on different spatial and temporal scales. The natural implication of these conditions is the oceanic circulation and layout, the thermal features of oceanic streams in the North Atlantic, and the interaction between the ocean and atmosphere in the formation of the main atmospheric mass flow over the European synoptic area (Marsz, Styszyńska 2002, 2006; Paszyński, Niedźwiedź 1991; Wibig 2000, 2001; Woś 1999, 2010; Żmudzka 2007). The transformation of these atmospheric masses over land, in addition to the duration and direction of advection, depends on many different features of land morphology and types of land cover and their physical properties. The variability of cloudiness over Poland depends not only on source areas and the path of atmospheric mass, but also on circulation epochs (Kożuchowski et al. 2000; Żmudzka 2007).

Based on these conclusions from the above citied papers $\mathrm{s}$, the current analysis confirms the conclusions of the earlier studies of the authors (Bryś, Bryś 2002; Bryś 2017), in that the teleconnections between the NAO and $K \downarrow$ in Central Europe have a very complicated and asynchronous character. Taking the example of August, Figure 8 shows some differences of this asynchronous character between the years 1959-1987 and 1988-2016, which are visible both in Wrocław and Potsdam, and demand a wider, more detailed analysis. The relations have a larger, climatological context jointed with long-term variations of circulation 

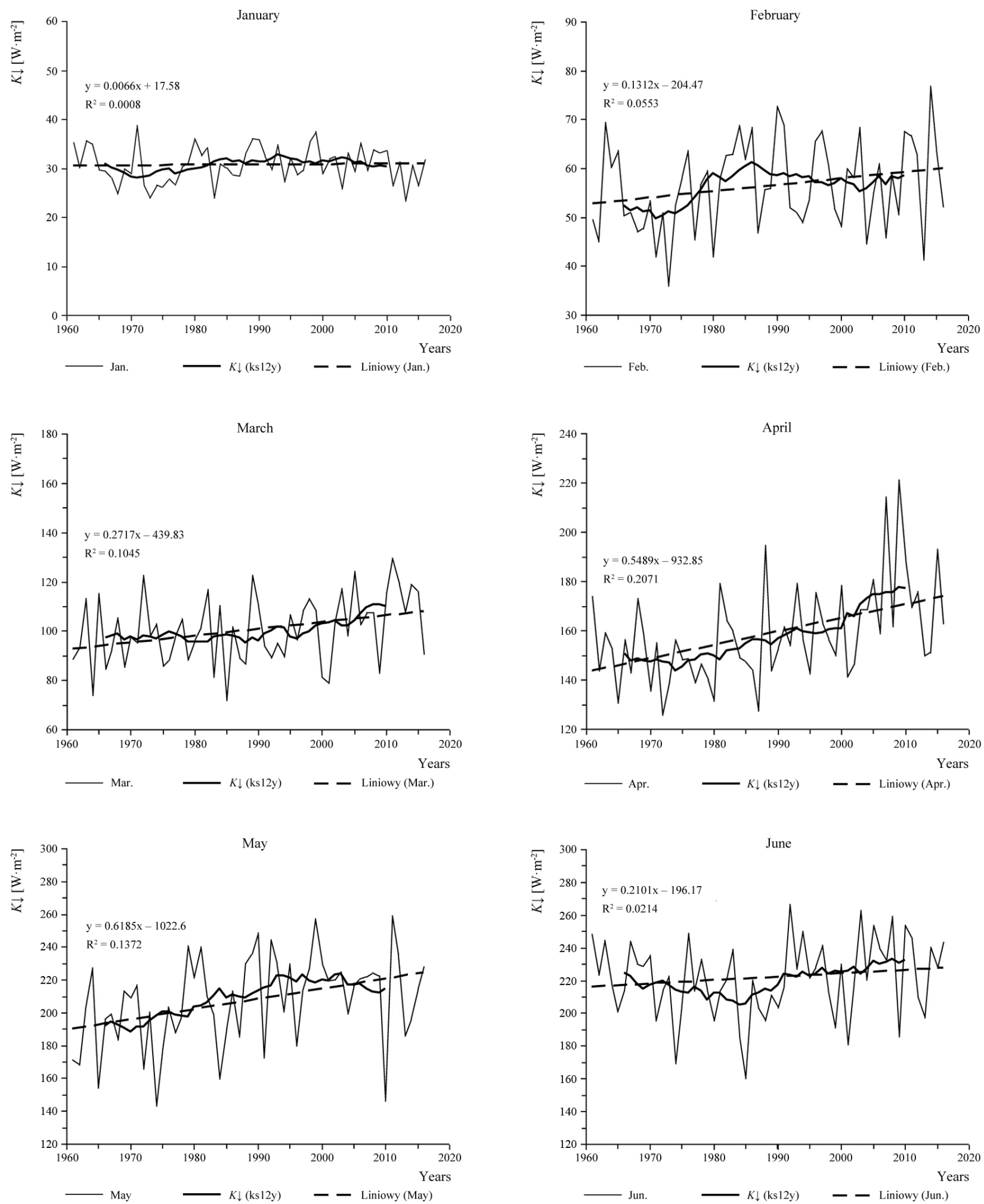

Fig. 4. The courses of average monthly values of global radiation intensity $K \downarrow$ and their 12 -year (ks12y) moving averages in WrocławSwojec in the years of 1961-2016 (Liniowy $=$ Linear trend $)-$ Part A 

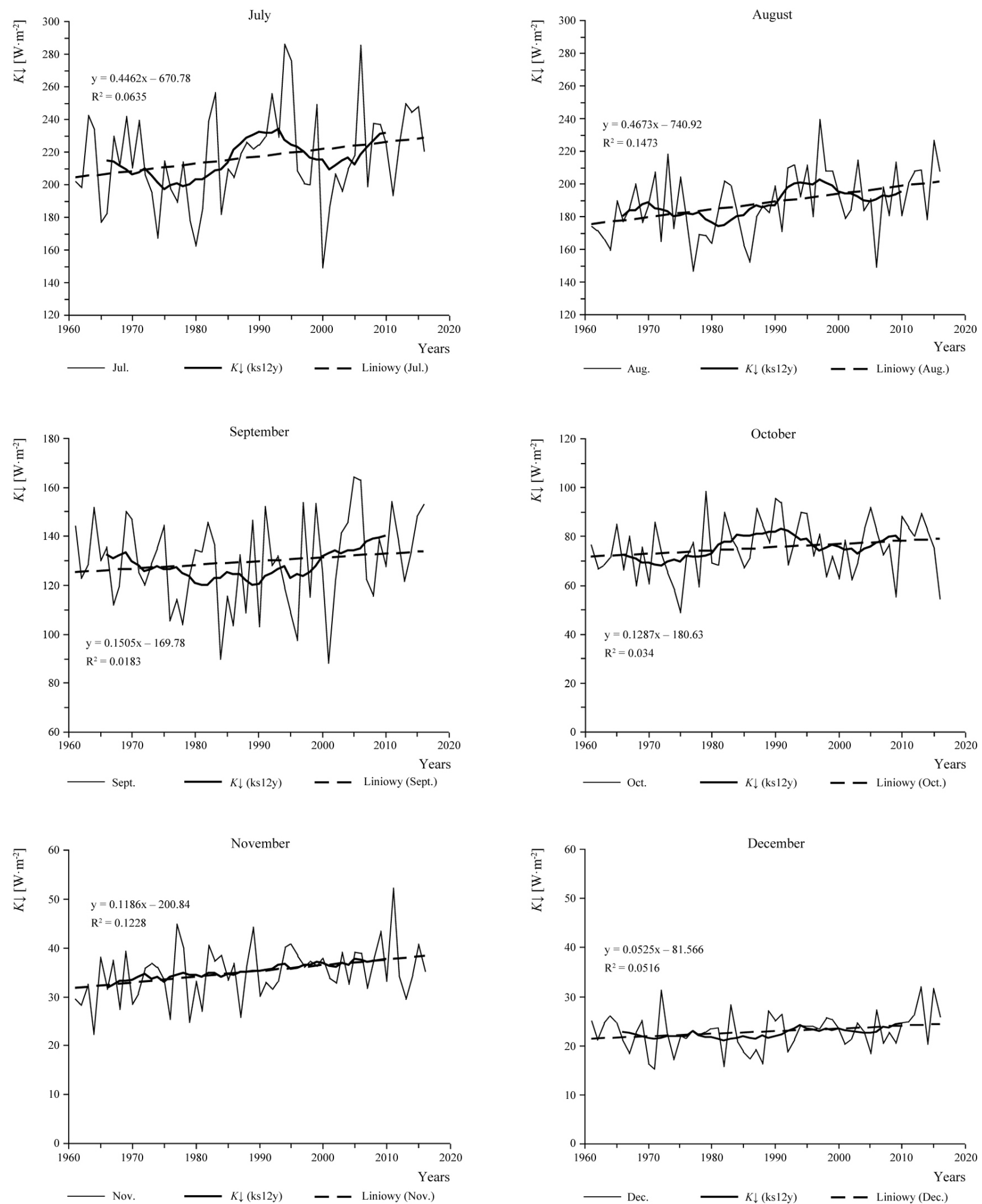

Fig. 4b. The courses of average monthly values of global radiation intensity $K \downarrow$ and their 12 -year (ks12y) moving averages in WrocławSwojec in the years of 1961-2016 $($ Liniowy $=$ Linear trend $)-$ Part B 


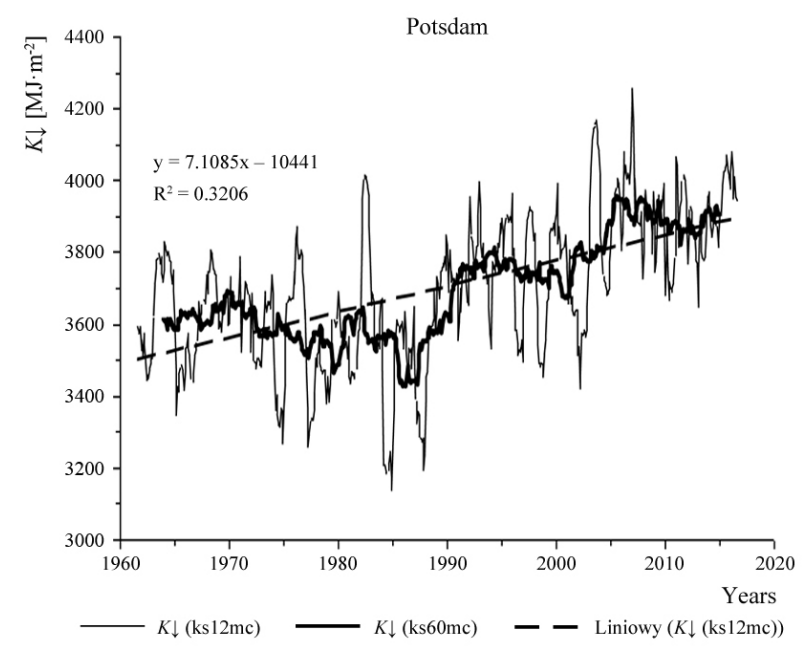

Fig. 5. The runs of 12- and 60-month (mean yearly values) moving sums (ks12m and ks60m) of global radiation $K \downarrow$ in Potsdam in the years of 1961-2016 (Liniowy = Linear trend)

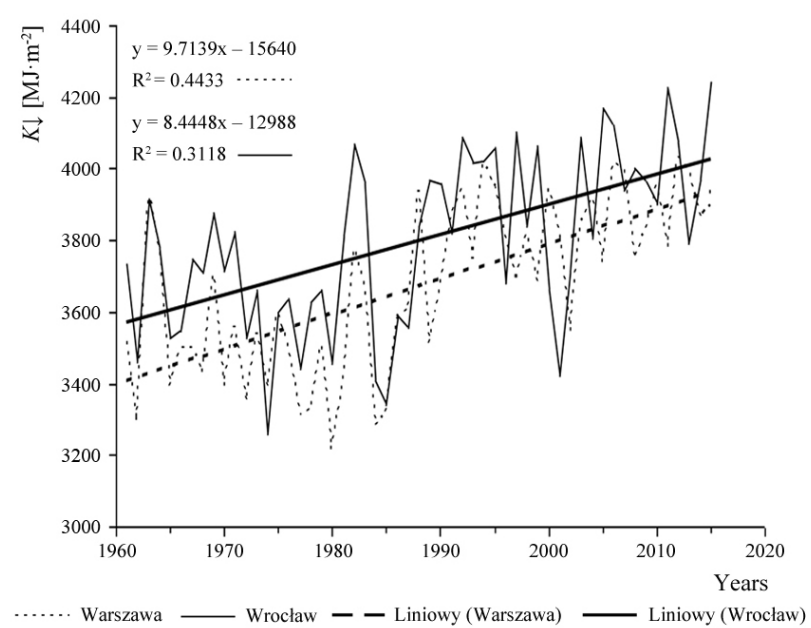

Fig. 7. The comparison of runs of annual (Jan.-Dec.) sums of $K \downarrow$ and their trends in Wrocław and Warsaw (Warszawa) in the years of 1961-2015 (Liniowy = Linear trend)

patterns in the synoptic broad scale not only over Europe and the North Atlantic, but also over the Middle East, the west part of Siberia and the north peripheries of Africa.

Strong positive phases of the NAO tend to be associated with above-average temperatures in northern Europe, and below-average temperatures across southern Europe and the Middle East. They are also associated with aboveaverage precipitation over northern Europe and Scandinavia in winter, and below-average precipitation over southern and central Europe. Opposite patterns of temperature and precipitation anomalies are typically observed during strong negative phases of the $\mathrm{NAO}^{5}$. Such spatial teleconnections of the winter NAO are likely to impact future barometric patterns over the European Synoptic Area (Marsz, Styszyńska 2006; Marsz 2010) and the directions

\footnotetext{
${ }^{5}$ http://www.cpc.ncep.noaa.gov/data/teledoc/nao.shtml
}

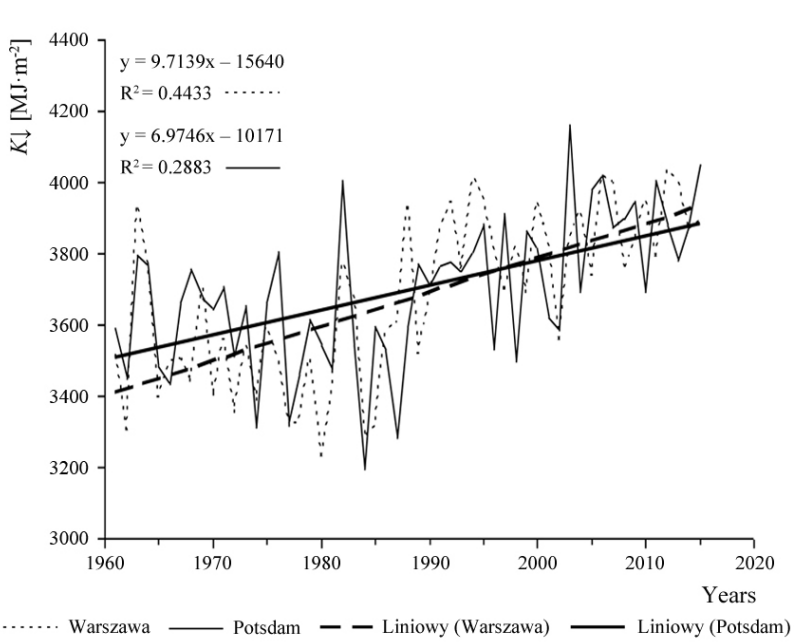

Fig. 6. The comparison of runs of annual (Jan.-Dec.) sums of $K \downarrow$ and their trends in Potsdam and Warsaw (Warszawa) in the years of 1961-2015 (Liniowy $=$ Linear trend)

and features of atmospheric advection in Central Europe during the summer.

A detailed analysis of these teleconnections demands a different study. In addition to the NAO, such analysis needs to also explore the topic of climatological influences of other circulation patterns on the main radiation climatic features in Poland and Central Europe.

\section{Summary}

The observed positive trends show significant increasing values of the investigated global radiation sums for Lower Silesia, Central Poland and the east part of Germany. The growth of the $K \downarrow$ sums is linked to the macro-regional circulation changes, particularly with the basic stages of the NAO positive phase and their influence on the weather in Central Europe. The first, juvenile stage of the phase (the 1970s and 1980s), when annual sums of $K \downarrow$ in WrocławSwojec only reached the average level of approximately $3700 \mathrm{MJ} \cdot \mathrm{m}^{-2}$ and the warm half-year approximately $2800 \mathrm{MJ} \cdot \mathrm{m}^{-2}$, was cloudy and rainy. This period was distinctly different compared to the advanced stage (the 1990s and later years), with a longer sunshine duration and smaller annual precipitation, with adequate radiation sums amounting to $3900-4000 \mathrm{MJ} \cdot \mathrm{m}^{-2}$ and $3000-3100 \mathrm{MJ} \cdot \mathrm{m}^{-2}$, respectively. Similar variations were reached in Warsaw and Potsdam. The noted trends and periods of solar change are linked to similar variations in cloudiness and sunshine duration, which are typically observed in Poland (Bryś 2015; Dubicka, Pyka 2001; Koźmiński, Michalska 2005; Matuszko 2009; Morawska-Horawska 1985, 2002; Podstawczyńska 2003, 2007) and Central Europe (Bryś 2013, Ohrvil et al. 2009). The paper confirms the conclusions of previous studies made by the authors (Bryś 2013, 2015, 2017; 

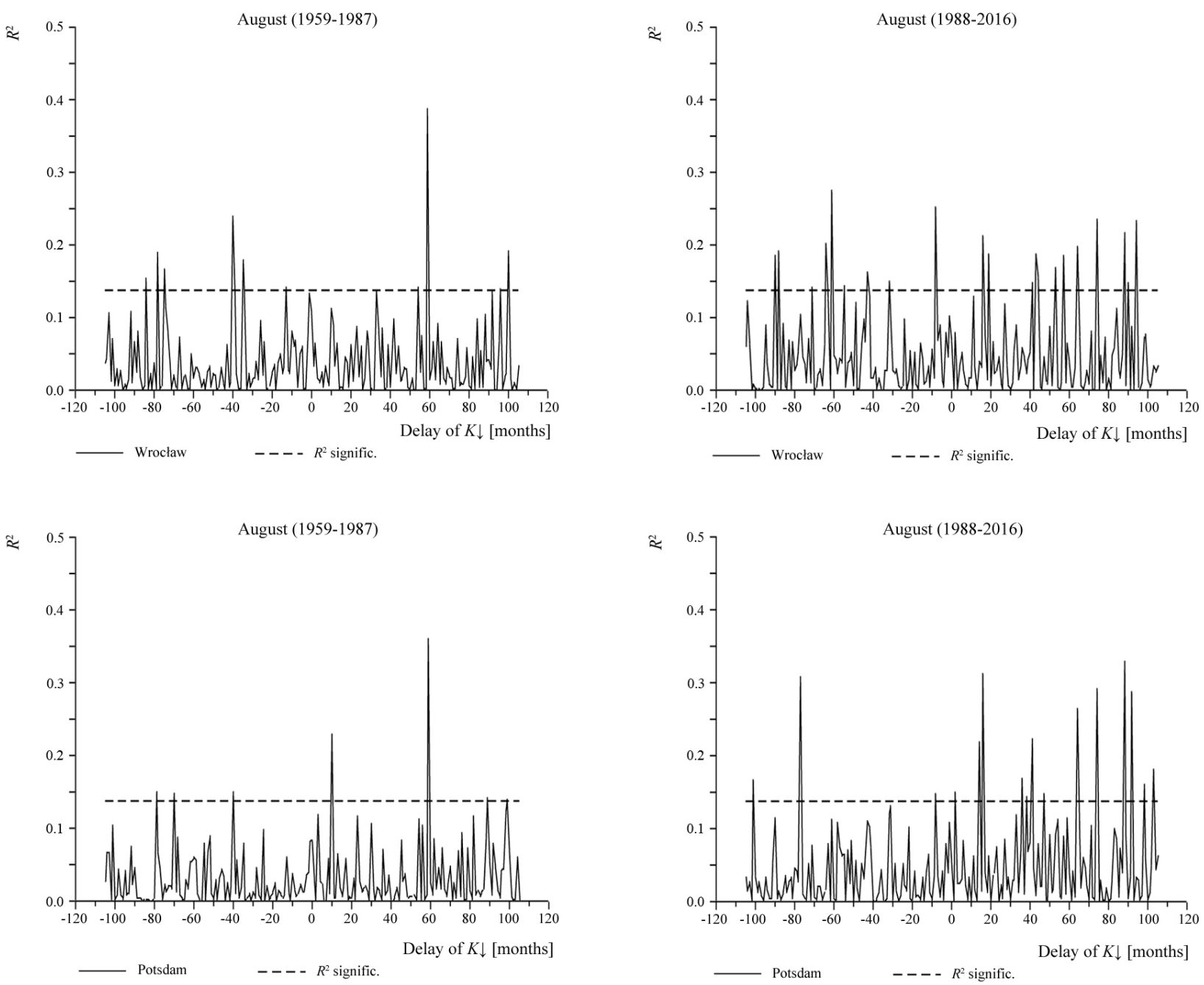

Fig. 8. The comparison of runs of the asynchronous coefficient of determination $\left(R^{2}\right)$ for the correlations between monthly indices of the NAO and monthly sums of $K \downarrow$ in Wrocław and Potsdam in the years 1959-1987 and 1988-2016 for the month of August. Explanation: delay of $K \downarrow$ from -105 to 105 months, 0 - the synchronous correlation, $R 2$ significant. - the lower boundary of a value for the coefficient of determination $\left(R^{2}\right)$, which is statistical significant

Bryś, Bryś 2002, 2003, 2007), on the main role of naturally observed radiation trends. The derived results point out that radiation trends are strongly connected to natural long-term macro-circulation changes (Marsz 2005, Marsz, Styszyńska 2002, 2006, 2009; Ohrvil et al. 2009; Pisek, Brazdil 2006) in the Northern Hemisphere. In addition to influences of other north hemispheric barometric patterns (Marsz, Styszyńska 2006), they are relatively strongly related to the phases and sub-phases of the North Atlantic Oscillation. These atmospheric changes are connected with long-term changes in oceanic circulation, particularly with wind-driven circulation or the meridional overturning circulation (MOC) and the behaviors and features of oceanic surface currents (Marsz, Styszyńska 2009; Olbers et al. 2012). Teleconnections most often have an asynchronous character and perform quasi-periodically, with several year long waves of radiation changes as an important phenomenon for many years of climatic fluctuations. Further studies should involve a detailed analysis of atmospheric pollution emissions and their influence on global radiation. Such studies can determine whether the macro-circulation, natural genesis of the radiation changes is more important than the influence of anthropogenic aerosols on climate, as suggested by Ahrens (2008), Wibig (2009) and other researchers that support the main theses of the IPCC Report (2013).

\section{Bibliography}

Abakumova G.M., Feigelson E.M., Russak V., Stadnik V.V., 1996, Evaluation of long-term changes in radiation, cloudiness and surface temperature on the territory of the former Sowiet Union, Journal of Climate, 9 (6), 1319-1327, DOI:10.1175/1520-0442(1996)009<1319:EOLTCI>2.0.CO;2 Abakumova G.M., Gorbarenko E.V., 2008, Transparency in Moscow during the last 50 years, its changes on the territory of Russia, (in Russian), Izdatelstvo LKI, Moscow, 193 pp.

Ahrens C.D., 2008, Meteorology today: an introduction to weather, climate and the environment, Cengage Learning, $624 \mathrm{pp}$. 
Alpert P., Kishcha P., Kaufman Y.J., Schwarzbard R., 2005, Global dimming or local dimming? Effect of urbanization on sunlight availability, Geophysical Research Letters, 32 (17), L17802, DOI: 10.1029/2005GL023320

Bogdańska B., Podogrocki J., 2000, Variation in global solar radiation on Polish territory in the period 1961-1995, (in Polish), Materiały Badawcze IMGW. Seria: Meteorology, 30, 43 pp.

Bryś K., 2006, Radiation potential of Lower Silesia as a source for utilization of solar energy in the future, (in Polish), [in:] Zintegrowany Program Operacyjny Rozwoju Regionalnego. Biuletyn Innowacyjny CEPRIN, Europejski Fundusz Społeczny, Wrocław, 19-31

Bryś T., 2007a, Study of representativeness for the WrocławSwojec observatory as an agrimeteorological and climatic station, (in Polish), [in:] Zintegrowany Monitoring Środowiska Przyrodniczego, A. Kostrzewski, A. Andrzejewska (eds.), Biblioteka Monitoringu Środowiska, Warszawa, 255-267

Bryś K., 2007b, Variability of sunshine duration in WrocławSwojec in the years 1961-2006 on the background of its secular changes, (in Polish), [in:] Funkcjonowanie i monitoring geoekosystemów Polski w warunkach narastającej antropopresji, A. Kostrzewski, A. Andrzejewska (eds.), Biblioteka Monitoringu Środowiska, Warszawa, 243-255

Bryś K., 2013, Dynamics of net radiation balance of grass surface and bare soil, (in Polish), Monografie Uniwersytetu Przyrodniczego we Wrocławiu, 162, 288 pp.

Bryś K., 2015, Resources of solar energy in the valley of the Widawa River, (in Polish), Inżynieria Ekologiczna, 44, 53-61, DOI: 10.12912/23920629/60025

Bryś K., 2017, Variability of solar features of Lower Silesia agroclimate, (in Polish), Zeszyty Naukowe Uniwersytetu Przyrodniczego we Wrocławiu: Rolnictwo, 624, 15-31

Bryś K., Bryś T., 2002, Influence of the NAO changes on a variability of the humidity, radiation, wind dynamics and evaporation in Wrocław-Swojec in the years 1946-2000, (in Polish), [in:] Oscylacja Północnoatlantycka i jej wpływ na warunki klimatyczne i hydrologiczne Polski, A.A. Marsz, A. Styszyńska (eds.), Akademia Morska, Gdynia, 147-160

Bryś K., Bryś T., 2003, Fluctuations of global solar radiation in $20^{\text {th }}$ century at Wrockaw and their relations to Wolf's number and circulation changes, Acta Universitatis Wratislaviensis. Studia Geograficzne, 75, 189-202

Bryś K., Bryś T., 2007, Variability of solar features of the Wrocław climate in the years 1875-2004, (in Polish), Pamiętnik Puławski, 144, 13-34

Dubicka M., 1994, Influence of atmospheric circulation on the climate conditions shaping (on Wroclaw example), (in Polish), Acta Universitatis Wratislaviensis. Studia Geograficzne, 60, $296 \mathrm{pp}$

Dubicka M., 1998, Ninety-five-year series of the sunshine duration measurements on Mount Śnieżka, (in Polish), [in:] Geoe- kologiczne Problemy Karkonoszy, Wydawnictwo Acarus, Poznań, 133-144

Dubicka M., Karal J., 1994, Sunshine duration on Mount Szrenica and its relation to atmospheric circulation, (in Polish), Acta Universitatis Wratislaviensis. Prace Instytutu Geograficznego. Seria C: Meteorologia i Klimatologia, 1, 9-43

Dubicka M., Karal J., Ropuszyński P., 1995, Sunshine duration in Wrocław in the years 1981-1992 on the background of the secular measurement series, (in Polish), Acta Universitatis Wratislaviensis. Prace Instytutu Geograficznego. Seria C: Meteorologia i Klimatologia, 2, 5-21

Dubicka M., Limanówka D., 1994, Variability of cloudiness and sunshine duration in the Sudeten and Carpathian Mts. and their foothills, (in Polish), Acta Universitatis Wratislaviensis. Prace Instytutu Geograficznego. Seria C: Meteorologia i Klimatologia, 1, 45-60

Dubicka M., Migała K., 1997, Variation of sunshine duration in selected mountains regions of Central Europe, (in Polish), Acta Universitatis Wratislaviensis. Prace Instytutu Geograficznego. Seria C: Meteorologia i Klimatologia, 4, 31-41

Dubicka M., Pyka J.L., 2001, Climate of Wrocław in $20^{\text {th }}$ century, (in Polish), Prace i Studia Geograficzne, 29, 101-112

Górski T., Górska K., 2000, Sunshine duration in Puławy in span of the years 1923-1992, (in Polish), Acta Universitatis Nicolai Copernici. Geografia. Nauki Matematyczno-Przyrodnicze, 106, 141-156

Hurrell J.W., 1995, Decadal trends in the North Atlantic Oscillation: regional temperatures and precipitation, Science, 269 (5224), 676-679, DOI: 10.1126/science.269.5224.676

IPCC, 2013, Climate change 2013: the physical science basis, Contribution of Working Group I to the Fifth Assessment Report of the Intergovernmental Panel on Climate Change, IPCC, Cambridge University Press, Cambridge, United Kingdom and New York, NY, USA, 1535 pp.

Jaworowski Z., 2003, Solar cycles, not $\mathrm{CO}_{2}$, determine climate, 21st Century Science and Technology, 52-65, available at https://21sci-tech.com/Articles\%202004/Winter2003-4/ global_warming.pdf (data access 31.01.2019)

Jaworowski Z., 2007, $\mathrm{CO}_{2}$ : The greatest scientific scandal of our time, EIR Science, 38-53, available at http://folk.uio. no/tomvs/esef/Jaworowski\%20CO2\%20EIR\%202007.pdf (data access 31.01.2019)

Kleniewska M., Chojnicki B.H., Acosta M., 2016, Long-term total solar radiation variability at the Polish Baltic coast in Kołobrzeg with in the period 1964-2013, Meteorology, Hydrology and Water Management, 4 (2), 35-40, DOI: 10.26491/mhwm/64594

Kondratyev K.Y., Galindo I., 1997, Volcanic activity and climate. A Deepak Publishing, Hampton, VA, USA, 382 pp. 
Koźmiński C., Michalska B., 2005, Sunshine duration in Poland, (in Polish), Akademia Rolnicza w Szczecinie, Uniwersytet Szczeciński, Szczecin, 110 pp.

Kożuchowski K., Degirmendzić J., Fortuniak, K., Wibig J., 2000, Trends to changes in seasonal aspects of the climate of Poland. Geographia Polonica, 73 (2), 7-24

Kuczmarska L., Kuczmarski M., 1998, Structure of sunshine duration in Poland, (in Polish), Przegląd Geograficzny, 1/2, 101-110

Kuczmarski M., 1990, Sunshine duration of Poland and its usefulness for heliotherapy, (in Polish), Dokumentacja Geograficzna, 4, $70 \mathrm{pp}$.

Marsz A.A., 2005, About oceanic conditionings of circulation and thermal nature of wintertime in Poland and the middle Europe, (in Polish), Akademia Morska, Gdynia, 63 pp.

Marsz A.A., 2010, Role interzonal meridional circulation over the east of the North Atlantic in a shaping of some climate features of the Atlantic Arctic, (in Polish), Problemy Klimatologii Polarnej, 20, 7-30

Marsz A., Styszyńska A., 2002, North Atlantic Oscilllation and its influence on climatic and hydrological conditions in Poland, (in Polish) Akademia Morska, Gdynia, 222 pp.

Marsz A., Styszyńska A., 2006, About „Arctic” and „Atlantic” mechanisms which control variability of the air temperature on Europe territory and the north-west Asia, (in Polish), Problemy Klimatologii Polarnej, 16, 47-89

Marsz A.A., Styszyńska A., 2009, Oceanic control of the warming processes in the Arctic - a different point of view for the reasons of changes in the Arctic climate, Problemy Klimatologii Polarnej, 19, 7-31

Matuszko D., 2009, Influence of cloudiness on sunshine duration and global solar radiation on example of the Cracow measurement series, (in Polish), Wydawnictwo Uniwersytetu Jagiellońskiego, Kraków, 232 pp.

Matuszko D., 2012, Influence of the extent and genera of cloud cover on solar radiation intensity, International Journal of Climatology, 32 (15), 2403-2414, DOI: 10.1002/joc.2432

Matuszko D., 2014, Long-term variability in solar radiation in Krakow based on measurements of sunshine duration, International Journal of Climatology, 34 (1), 228-234, DOI:10.1002/joc.3681

Marciniak K., Wójcik G., 1991, The variation of sunshine duration in the middle part of northern Poland during the period 1946-1989, Zeszyty Problemowe Postępów Nauk Rolniczych, 396, 109-115

Morawska-Horawska M., 1985, Cloudiness and sunshine in Cracow 1861-1980 and its contemporary tendencies, International Journal of Climatology, 5 (6), 633-642, DOI: 10.1002/joc. 3370050605

Morawska-Horawska M., 2002, Tendencies of cloudiness and sunshine duration in Cracow 1861-1990, (in Polish), [in:]
Działalność naukowa prof. Władysława Gorczyńskiego i jej kontynuacja, G. Wójcik, K. Marciniak (eds.), Wydawnictwo Naukowe Uniwersytetu Mikołaja Kopernika, Toruń, 341-351 Norris J.R., Wild M., 2007, Trends in aerosol radiative effects over Europe inferred from observed cloud cover, solar "dimming," and solar "brightening", Journal of Geophysical Research: Atmospheres, 112 (D8), DOI: 10.1029/2006JD007794

Ohvril H., Teral H., Lennart N., Kannel M., Uustare M., Tee M., Russak V., Okulov O., Jõeveer A., Kallis A., Ohvril T., Terez E., Terez G., Gushchin G.K., Abakumova G.M., Gorbarenko E.V., Tsvetkov A.V., Laulainen N., 2009, Global dimming and brightening versus atmospheric column transparency, Europe, 1906-2007, Journal of Geophysical Research: Atmospheres, 114 (D10), DOI: 10.1029/2008JD010644

Olbers D., Willebrand J., Eden C., 2012, Ocean dynamics, Springer, Berlin, Heidelberg, 708 pp.

Paszyński J., Niedźwiedź T., 1991, Climate, (in Polish), [in:] Geografia Polski - środowisko przyrodnicze, L. Starkel (ed.), PWN, Warszawa, 288-343

Pisek J., Brázdil J., 2006, Responses of large volcanic eruptions in the instrumental and documentary climatic data over Central Europe, International Journal of Climatology, 26 (4), 439-459, DOI: $10.1002 /$ joc. 1249

Podogrocki J., 1984, Solar radiation at selected stations of the Polish network 1983 and 1961-1980, Publications of the Institute of Geophysics Polish Academy of Science. Physics and Atmosphere, D-20 (178), 45-52

Podogrocki J., 1989, On solar energy resources in Poland during the vegetation period, Zeszyty Problemowe Postępów Nauk Rolniczych, 396, 245-250

Podogrocki J., 2001, The chart of spatial distribution of global solar radiation intensity in Poland, (in Polish), [in:] Atlas klimatycznego ryzyka uprawy roślin w Polsce, C. Koźminski, B. Michalska (eds.), Uniwersytet Szczeciński, Szczecin, 26 a-c Podogrocki J., 2007, Climatic and meteorological conditions to an utilization of the solar radiation energy in Poland, (in Polish), available at http://solis.pl/index.php/ pliki_do_pobrania/publikacje_i_artykuly/warunki_do_wykorzystania_energii_promieniowania_slonecznego_w_polsce (31.01.2019)

Podogrocki J., Słomka J., 1993, Selected results of many year recording of sunshine duration in Warsaw and Belsk, Publications of the Institute of Geophysics Polish Academy of Science. Physics and Atmosphere, D-40 (263), 83-???

Podstawczyńska A., 2003, Variability of sunshine duration in Łódź in 1951-2000. Acta Universitatis Wratislaviensis. Studia Geograficzne, 75, 295-304

Podstawczyńska A., 2007, Solar features of the Lodz's climate, (in Polish), Acta Universitatis Lodziensis. Folia Geographica Physica, 7, 294 pp. 
Ruckstuhl C., Norris J.R., 2009, How do aerosol histories affect solar "dimming" and "brightening" over Europe? IPCC-AR4 models versus observations, Journal of Geophysical Research: Atmospheres, 114 (D10), DOI: 1029/2008 JD011066

Russak V.K., 1987, On modern changes in atmospheric transparency, Mieteorologija i Gidrologija, 3, 53-57

Russak V.K., 1990, Trends of solar radiation, cloudiness and atmospheric transparency during recent decades in Estonia, Tellus, 42 (2), 206-210, DOI: 10.1034/j.1600-0889.1990. t01-1-00006.x

Sanchez-Lorenzo A., Brunetti M., Calbó J., Martin-Vide J., 2007, Recent spatial and temporal variability and trends of sunshine duration over the Iberian Peninsula from a homogenized dataset, Journal of Geophysical Research: Atmospheres, 112 (D20), DOI: 10.1029/ 2007JD008677

Sanchez-Lorenzo A., Enriquez-Alonso A., Wild M., Trentmann J., Vicente-Serrano S.M., Sanchez-Romero A., Posselt R., Hakuba M.Z., 2017, Trends in downward surface solar radiation from satellites and ground observations over Europe during 1983-2010, Remote Sensing of Environment, 189, 108-117, DOI: 10.1016/j.rse.2016.11.018

Soon W.H., Posmentier E.S., Baliunas S.L., 1996, Inference of solar irradiance variability from terrestrial temperature changes 1880-1993: an astrophysical application of the sun-climate connection, The Astrophysical Journal, 472 (2), 891-902

Stanhill G., 2005, Global dimming: a new aspect of climate change, Weather, 60 (1), 11-14, DOI: 10.1256/wea.210.03

Stanhill G., 2007, A perspective on global warming, dimming, and brightening, Eos, Transactions. American Geophysical Union, 88 (5), 58-59, DOI: 10.1029/2007EO050007

Stanhill G., Cohen S., 2001, Global dimming: a review of the evidence for a widespread and significant reduction in global radiation with discussion of its probable causes and possible agricultural consequences, Agricultural and Forest Meteorology, 107 (4), 255-278, DOI: 10.1016/S0168-1923(00)00241-0

Stanhill G., Cohen S., 2005, Solar radiation changes in the United States during the twentieth century: evidence from sunshine duration measurements, Journal of Climate, 18 (10), 15031512, DOI: 10.1175/JCLI3354.1

Streets D.G., Wu Y., Chin M., 2006, Two-decadal aerosol trends as a likely explanation of the global dimming/brightening transition, Geophysical Research Letters, 33 (15), DOI: 10.10 29/2006GL026471

Stjern C.W., Kristjánsson J.E., Hansen A.W., 2009, Global dimming and global brightening - an analysis of surface radiation and cloud cover data in northern Europe, International Journal of Climatology, 29 (5), 643-653, DOI: 10.1002/joc.1735

Sun B., Groisman P.Y., 2000, Cloudiness variations over the former Soviet Union, International Journal of Climatology, 20 (10), 1097-1111, DOI: 10.1002/1097-0088(200008)20:10<1097: AID-JOC541>3.0.CO;2-5
Tooming H., 2002, Dependence of global radiation on cloudiness and surface albedo in Tartu, Estonia, Theoretical and Applied Cimatology, 72 (3-4), 165-172, DOI: 10.1007/s00704-0020671-y

Uscka-Kowalkowska J., 2008a, Direct solar radiation and its extinction by the atmosphere in Kołobrzeg in the years 19602000, (in Polish), Acta Agrophysica, 12 (1), 221-233

Uscka-Kowalkowska J., 2008b, Direct solar radiation and its extinction by the atmosphere on an example of Puławy and Papowo, (in Polish), Wydawnictwo Naukowe UMK, Torun, 133 pp.

Uscka-Kowalkowska J., 2009, Comparison of direct solar radiation and its extinction by the atmosphere in Warsow and Mikołajki, (in Polish), Acta Agrophysica, 14 (2), 501-514

Uscka-Kowalkowska J., 2013, An analysis of the extinction of direct solar radiation on Mt. Kasprowy Wierch, Poland, Atmospheric Research, 134, 175-185, DOI: 10.1016/j.atmosres.2013.08.002

Warren S.G., Eastman R.M., Hahn C.J., 2007. A survey of changes in cloud cover and cloud types over land from surface observations, 1971-96, Journal of Climate, 20 (4), 717-738, DOI: $10.1175 /$ JCLI4031.1

Wibig J., 2000, The North Atlantic Oscillation and its impact of weather and climate, (in Polish), Przegląd Geofizyczny, 45 (2) $121-137$

Wibig J., 2001, Influence of atmospheric circulation on spatial distribution of temperature and precipitation anomalies in Europe, (in Polish), Rozprawy Habilitacyjne Uniwersytetu Łódzkiego, 208 pp.

Wibig J., 2003, Cloudiness variability in Łódź between 1931 and 2000, Acta Universitatis Wratislaviensis. Studia Geograficzne, 75, 305-316

Wibig J., 2004, Long-term variability of cloudiness and its relation to precipitation on the example of Łódź, [in:] Potential climate changes and sustainable water management, M. Liszewska (ed.), Monographic E-4 (377), 25-32

Wibig J., 2009, Contemporary climatic changes - presumptions of an influence of the anthropogenic factors, (in Polish), available at http://www.klimat.geo.uj.edu.pl/strony/studenci/ artykuly/Artykuly_rozne/JWibig_antropo.pdf (data access 01.02.2019)

Wild M., 2009, Global dimming and brightening: a review, Journal of Geophysical Research: Atmospheres, 114 (D10), DOI: 10.1029/2008JD011470

Wild M., Gilgen H., Roesch A., Ohmura A., Long C.N., Dutton E., Forgan B., Kallis A., Russak V., Tsvetkov A., 2005, From dimming to brightening: decadal changes in solar radiation at earth's surface, Science, 308 (5723), 847-850, DOI: $10.1126 /$ science. 1103215 
Wild M., Ohmura A., Makowski K., 2007, Impact of global dimming and brightening on global warming, Geophysical Research Letters, 34 (4), DOI: 10.1029/2006GL028031

Wild M., Trüssel B., Ohmura A., Long C.N., König-Langlo G., Dutton E.G., Tsvetkov A., 2009, Global dimming and brightening: an update beyond 2000, Journal of Geophysical Research: Atmospheres, 114 (D10), DOI: 10.1029/2008JD011382

Wilks D., 2005, Statistical methods in the atmospheric sciences, Academic Press, 649 pp.
Woś A., 1999, Climate of Poland, (in Polish), Wydawnictwo Naukowe PWN, Warszawa, 302 pp.

Woś A., 2010, Climate of Poland in the second half of $20^{\text {th }}$ century, (in Polish), Wydawnictwo Naukowe UAM, Poznań, 489 pp.

Żmudzka E., 2007, Variability of cloudiness over Poland and its circulation conditions, (in Polish), Wydawnictwo Uniwersytetu Warszawskiego, Warszawa, 399 pp. 